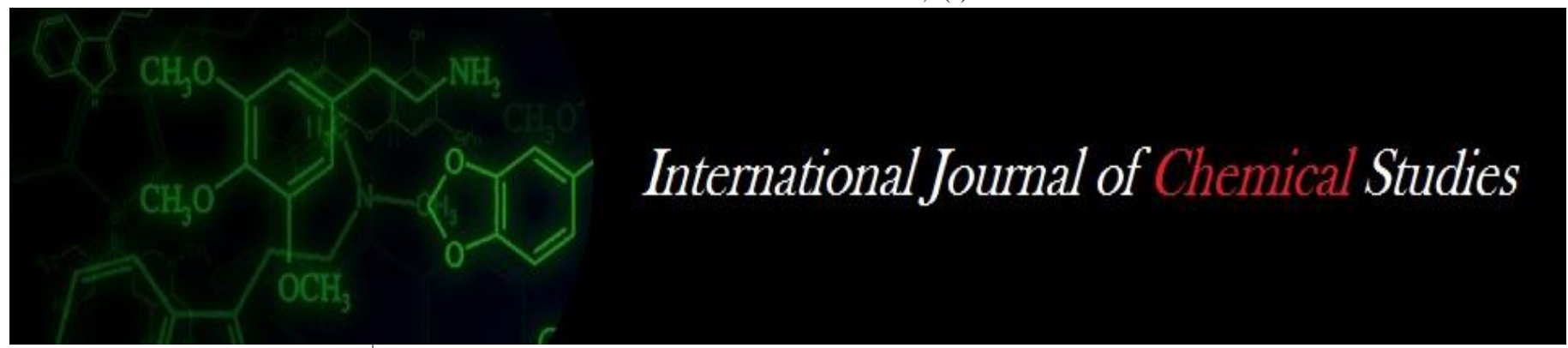

P-ISSN: 2349-8528

E-ISSN: 2321-4902

www.chemijournal.com

IJCS 2020; 8(3): 146-153

(C) 2020 IJCS

Received: 22-03-2020

Accepted: 24-04-2020

\section{Satish Sharma}

Department of Plant Pathology, College of Agriculture, R.V.S.K.

V.V. Gwalior, Madhya Pradesh, India

\section{Reeti Singh}

Department of Plant Pathology,College of Agriculture, R.V.S.K. V.V. Gwalior, Madhya Pradesh, India

\section{Ajay Kumar}

Department of Plant Pathology, College of Agriculture, R.V.S.K. V.V. Gwalior, Madhya Pradesh, India

\section{Corresponding Author:} Satish Sharma

Department of Plant Pathology, College of Agriculture, R.V.S.K. V.V. Gwalior, Madhya Pradesh, India

\section{The biochemical changes in cluster bean leaves due to Alternaria blight infection}

\author{
Satish Sharma, Reeti Singh and Ajay Kumar
}

DOI: https://doi.org/10.22271/chemi.2020.v8.i3b.9217

\begin{abstract}
Cluster bean is being grown in India since ancient time. Although believed to be of African origin (Vavilov, 1951), it was domesticated centuries ago in the north-western region of the Indo Pakistan subcontinent (Hymowitz, 1972). Tender green guar pods are important source of nutrition to human being and animals. Alternaria blight is an important disease as it acts as one of the limiting factors in its production. The present investigations and studies were carried on variability of pathogen and its disease management. The biochemical data indicate that the content of protein, total soluble sugar, reducing sugar and chlorophyll in diseased leaf of different varieties gradually and significantly decreased as compared to healthy leaf of same variety. In contrast the total phenol and O-dihydroxy phenol content were significantly increased in diseased leaf samples with the progress of the disease as compared to healthy leaf samples. Protein, total sugar, reducing sugar and chlorophyll contents were decreased with the infection of pathogen in the diseased sample whereas the total phenol and O-dihydroxy phenol were increased with increasing the disease in the diseased leaf sample of different varieties.
\end{abstract}

Keywords: Alternaria cucumerina var. cyamopsidis, biochemical analysis, clusterbean

\section{Introduction}

Cluster bean has become popular not only for consumption as vegetable but also as good source of useful industrial "Guar gum". Cluster bean commonly recognized as a summer, annual, drought-tolerant, well adapted to arid and semi-arid climates with hot temperatures legume crop. It can grow in sub humid conditions, from sea level upto an altitudes of $1000 \mathrm{~m}$ (Priya and Harika, 2016) ${ }^{[26]}$.

The disease appears year after year in mild to severe form since the pathogen is seed- borne in nature (Sowell, 1965) ${ }^{[37]}$. In early stages of infection, the water soaked spots appear on leaf blade which later turn greyish to dark brown with concentric zonations, demarcated with light brown lines inside the spot on the under surface. The lesions are light to grayish brown. Higher yield losses (43-78\%) were recorded when leaves were infected at seedling stage than at old stage (Sharma, 1981) ${ }^{[30]}$. For the assessment of nature of damage, caused by the pathogen, survey is essential. It also helps in identification of the specific pathogen species and its aggressiveness prevailing in a particular area.

The common biochemical constituents like chlorophyll, sugars and phenols are important in imparting resistant to the crop plants. But almost all living animals and plant show biochemical changes after infected by infectious agent (Bora and Joshi, 2013) ${ }^{[5]}$. The information regarding the biochemical changes in susceptible genotype under high degree severity is not available hence study is carried out with Alternaria blight susceptible variety to find out the biochemical changes in leaves under different disease intensity.

\section{Materials and Methods}

The leaves with different severity were collected and analyzed for the biochemical constituents viz., total phenols (Bray and Thorpe 1954) ${ }^{[7]}$, O-dihydroxy phenols (Mahadevan and Sridhar 1986) ${ }^{[21]}$, Total soluble protein (Bradford 1976) ${ }^{[6]}$, total soluble sugar (Sadasivam and Manikam 1992) ${ }^{[28]}$, Total reducing sugar (Somogyi 1952) ${ }^{[36]}$ and chlorophyl (Hiscox and Israelstam, 1979) ${ }^{[14]}$ and compared with healthy leaves. The healthy leaves were used as control. The biochemical parameters recorded on leaves was separately correlated with disease severity. 


\section{Extraction of Plant Tissues}

Estimation of metabolites requires their complete extraction from the tissue. In order to get reliable values, the activities of the enzymes which synthesize and utilize these metabolites need to be stopped at once. Though water is the universal solvent, it does not penetrate tissue quickly enough to stop enzymatic activity. In this context alcohol especially hot alcohol, is the best choice for the extraction.

\section{Procedure}

The treated leaf material was washed in distilled water and air-dried. Then the leaves were dried between blotting sheets and oven dried at $60^{\circ} \mathrm{C}$ overnight. The dried leaves were powdered and stored at $30^{\circ} \mathrm{C}$ till further use. One gram of the leaf powder was separately weighed and boiled at $100^{\circ} \mathrm{C}$ for $10 \mathrm{~min}$. The extract was cooled to room temperature and spun at $5000 \mathrm{rpm}$ for $10 \mathrm{~min}$. The supernatant was decanted and residue was again boiled in $80 \%$ alcohol and both the extracts were pooled and filtered through Whatman No. 41 filter paper and made up to $10 \mathrm{ml}$ with alcohol. Then the extracts were stored at $4{ }^{\circ} \mathrm{C}$.

\section{Principle}

The principle behind the Lowry method of determining protein concentrations lies in the reactivity of the peptide nitrogen[s] with the copper [II] ions under alkaline conditions and the subsequent reduction of the Folin Ciocalteu phosphomolybdic phosphor tungstic acid to hetero polymolybedenum blue by the copper-catalyzed oxidation of aromatic acids. Lowry method is sensitive to $\mathrm{pH}$ changes and therefore the $\mathrm{pH}$ of assay solution should be maintained at 10 - 10.5 (Bray and Thorpe 1954) ${ }^{[7]}$.

\section{Reagents}

- $2 \% \mathrm{Na}_{2} \mathrm{CO}_{3}$ in $0.1 \mathrm{~N} \mathrm{NaOH}$

- $1 \%$ NaK Tartrate in $\mathrm{H}_{2} \mathrm{O}$

- $0.5 \% \mathrm{CuSO}_{4} .5 \mathrm{H}_{2} \mathrm{O}$

- Reagent I: $48 \mathrm{ml}$ of A, $1 \mathrm{ml}$ of B, $1 \mathrm{ml} \mathrm{C}$

- Reagent II- 1 part Folin-Phenol: 1 part water BSA Standard - $1 \mathrm{mg} / \mathrm{ml}$

\section{Procedure}

- Took $0.2 \mathrm{ml}$ of BSA working standard in 5 test tubes and made up volume upto $1 \mathrm{ml}$ using distilled water.

- The test tube with $1 \mathrm{ml}$ distilled water served as blank.

- Added $4.5 \mathrm{ml}$ of Reagent I and incubate for 10 minutes.

- After incubation, added $0.5 \mathrm{ml}$ of reagent II and incubated for 30 minutes

- Measured the absorbance at $660 \mathrm{~nm}$.

\section{Estimation of total soluble sugars - Anthrone method}

The concentration of pentoses, hexoses. disaccharides including sucrose, lactose, maltose and hexuronic acids present either freely or along with polysaccharides were estimated using anthrone method (Sadasivam and Manikam 1992) [28]

\section{Principle}

Anthrone 10-keto-9.10-dihydro-anthracene a reduction product of anthoquinone reacts by condensing with carbohydrate furfural derivative to produce a green color in a solution and a blue color in a concentrated solution.

\section{Reagents Anthrone reagent}

- $2 \mathrm{~g}$ of anthrone in 11 of conc. $\mathrm{H}_{2} \mathrm{SO}_{4}$ (Prepared fresh).

\section{Procedure}

- Aliquots of $1 \mathrm{ml}$ of the extract pipette into test tubes.

- To each tube $4 \mathrm{ml}$ of the anthrone reagent was added allowing reagent to run down the side of the test tube.

- Tubes were capped to prevent the evaporation of water. Reaction mixture was incubated on boiling water bath for $10 \mathrm{~min}$.

- Tubes were cooled to room temperature in a cold water bath.

- Absorbance was measured at $625 \mathrm{nni}$ using spectrophotometer.

\section{Calculation}

Standard curve of glucose was prepared and calculated.

\section{Estimation of total phenols - Folin-Ciocalteu method}

Infection of plants induces changes in phenolic substances. Varieties differ in their response regard to phenolic changes. It has been suggested that the major difference between resistant and susceptible varieties is in the velocity of accumulation of phenols. The total phenol content was estimated by Folin-Ciocalteu (Bray and Thorpe 1954) ${ }^{[7]}$.

\section{Principle}

Estimation of phenols with Folin-Ciocalteu reagent is based on the reaction between phenols and an oxidizing agent Phospho-molybdate which results in the formation of a blue complex. The intensity of the color is measured in a colorimeter.

\section{Reagents}

- Folin-Ciocalteu reagent

- $20 \% \mathrm{Na}_{2} \mathrm{CO}_{3}$

\section{Procedure}

- $1 \mathrm{ml}$ of alcohol evaporated plant extract was taken in a test tube.

- $1 \mathrm{ml}$ of Folin- Ciocalteau reagent was added to it.

- $2 \mathrm{ml}$ of $\mathrm{Na}_{2} \mathrm{CO}_{3}$ solution was added to the above reaction mixture and heated in a boiling water bath exactly for $1 \mathrm{~min}$.

- The tube was cooled and diluted to $25 \mathrm{ml}$ with distilled water.

- The absorbance was measured at $650 \mathrm{~nm}$.

- A standard curve was made from different concentrations of catechol.

- Total phenol content was calculated by comparing absorbance value with standard.

Estimation of Ortho dihydroxy phenols - Arnow's method Ortho dihydroxy phenols are important in disease resistant reactions. They are easily oxidized by phenol oxidases and the resulting quinones are highly reactive and toxic to pathogens and their enzymes. The ortho-dihydroxy phenols were measured by the Arnow method. Arnow's reagent specifically reacts with ortho-dihydroxy phenols by producing a pink colored complex: the intensity of which was measured in a colorimeter.

\section{Reagents}

- $10 \mathrm{~g}$ of sodium nitrite $\left(\mathrm{NaNO}_{3}\right)$ and $10 \mathrm{~g}$ of sodium molybedate dissolved in $100 \mathrm{ml}$ of dist. water (Reagent stored in a brown bottle was stable for a year).

- HCI: $05 \mathrm{~N}$

- $\mathrm{NaOH}: \mathrm{IN}$ 


\section{Procedure}

$>1 \mathrm{ml}$ of the extract was pipetted into a test tube.

$>1 \mathrm{ml}$ of $0.5 \mathrm{~N} \mathrm{HCI}$. $1 \mathrm{ml}$ of Arnow's reagent. $10 \mathrm{ml}$ of dist. water and $2 \mathrm{ml}$ of IN $\mathrm{NaOH}$ were added.

$>$ Soon after the addition of the alkali, pink color appeared.

$>$ Reagent blank was without the extract.

$>$ In case of high color intensity the reaction mixture was diluted to $25 \mathrm{ml}$ and absorbance was recorded at $515 \mathrm{~nm}$.

$>$ Ortho dihydroxy phenols present in the samples were calculated from a standard solution prepared with catechol.

\section{Estimation of reducing sugar by Nelson-Somogyi method Principle}

The Nelson-Somogyi method is one of the classical and widely used methods for the quantitative determination of reducing sugars (Somogyi 1952) ${ }^{[36]}$. This method utilizes the reducing properties (because of the presence of a potential aldehyde or keto-groups) of certain types of carbohydrates. Determination of reducing sugars using Somogyi-Nelson is based on the absorbance at $520 \mathrm{~nm}$ of a coloured complex between a copper oxidized sugar and arsenomolybdate.

\section{Copper reagent}

- $180 \mathrm{~g} \mathrm{Na}_{2} \mathrm{SO}_{4}$

- 12 g potassium sodium tartrate

- $24 \mathrm{~g} \mathrm{Na}_{2} \mathrm{CO}_{3}$ (anhydrous)

- $4 \mathrm{~g} \mathrm{CuSO}_{4} .5 \mathrm{H}_{2} \mathrm{O}$ and $2.6 \mathrm{~g} \mathrm{CuSO}_{4}$

- $16 \mathrm{~g} \mathrm{NaHCO}_{3}$

\section{Preparation}

- Dissolved $12 \mathrm{~g}$ of potassium sodium tartrate and $24 \mathrm{~g}$ $\mathrm{Na}_{2} \mathrm{CO}_{3}$ in $250 \mathrm{ml} \mathrm{H} \mathrm{H}_{2} \mathrm{O}$. Followed by continuous stirring add $4 \mathrm{~g} \mathrm{CuSO}_{4} .5 \mathrm{H}_{2} \mathrm{O}$ in $16 \mathrm{~g} \mathrm{NaHCO}_{3}$.

- Dissolved $180 \mathrm{~g}$ of $\mathrm{Na}_{2} \mathrm{SO}_{4}$ in $500 \mathrm{ml}$ of boiling water $\mathrm{H}_{2} \mathrm{O}$ and boil to remove air bubbles.

- The two solutions were mixed and filtered hot to obtain a clear solution.

\section{Nelson reagent}

- $25 \mathrm{~g}\left(\mathrm{NH}_{4}\right) 2 \mathrm{MoO}_{4} .2 \mathrm{H}_{2} \mathrm{O}$ or $25 \mathrm{~g}\left(\mathrm{NH}_{4}\right) 6 \mathrm{Mo}_{7} \mathrm{O}_{4} .4 \mathrm{H}_{2} \mathrm{O}$.

- $21 \mathrm{~cm}^{3} \mathrm{H}_{2} \mathrm{SO}_{4}$

- 3 g AsHNa2O $\mathrm{g}_{4} .7 \mathrm{H}_{2} \mathrm{O}$

\section{Preparation}

- Dissolved $25 \mathrm{~g} \quad\left(\mathrm{NH}_{4}\right) 2 \mathrm{MoO}_{4} . \quad 2 \mathrm{H}_{2} \mathrm{O}$ or $25,75 \mathrm{~g}$ $\left(\mathrm{NH}_{4}\right) 6 \mathrm{Mo}_{7} \mathrm{O}_{24} .4 \mathrm{H}_{2} \mathrm{O}$ in $450 \mathrm{~cm}^{3} \mathrm{H}_{2} \mathrm{O}$ and add $21 \mathrm{~cm} 3$ $\mathrm{H}_{2} \mathrm{SO}_{4}$ (concentrated)

- Dissolved 3g AsHNa $\mathrm{O}^{4} .7 \mathrm{H}_{2} \mathrm{O}$ in $25 \mathrm{~cm}^{3} \mathrm{H}_{2} \mathrm{O}$

- Mixed both reagents and incubate $30 \mathrm{~min}$. in $55^{\circ} \mathrm{C}$

\section{Procedure}

- Prepared carbohydrate standardise distilled water ranging from $0-0,50 \mu \mathrm{m} / \mathrm{ml}$.

- Added $1 \mathrm{ml}$ of each standard to separate tubes. To the tubes used as the blanks, add $1 \mathrm{ml}$ of distilled water.

- Prepared the unknown samples in an appropriate dilution.

- To each tubes, added $1 \mathrm{ml}$ of the Copper Reagent and mix.

- Placed the tubes in boiling water for 10 minutes.

- Cooled the tubes to room temperature and add $1 \mathrm{~mL}$ of arsenomolybdate reagent - Nelson Reagent to all the tubes.

- Measured the absorbance at $520 \mathrm{~nm}$.

\section{Determination of chlorophyll content}

The chlorophyll content was estimated (Hiscox and Israelstam, 1979) ${ }^{[14]}$ by adding $10 \mathrm{ml}$ of DMSO (Dimethyl sulphoxide) to $50 \mathrm{mg}$ finely chopped fresh leaves. The test tubes were then heated at constant temperature of $65^{\circ} \mathrm{C}$ for 3 hrs. in an oven or water bath. The content was shaken once or twice during incubation period. After $3 \mathrm{hrs,} \mathrm{absorbance} \mathrm{was}$ taken at $645 \mathrm{~nm} \& 663 \mathrm{~nm}$. The blank used was of pure DMSO.

\section{Results and Discussion}

Plants have developed an arsenal of defence mechanisms to protect themselves against pathogen attacks. The data in the Table 1. revealed that there was variation in biochemical analysis in healthy and diseased leaves of resistant and susceptible genotypes due to Alternaria blight infection in Cluster bean after 50 DAS (Figure 1).

\section{Protein}

The healthy moderately resistant genotypes showed maximum and significantly higher protein content in comparison to susceptible genotypes. The result data revealed that the healthy MR variety RGC 1033 had highest protein 23.35 $\mathrm{mg} / \mathrm{g}$ which become decreased $(22.45 \mathrm{mg} / \mathrm{g})$ in the pathogen infected leaf samples and it was followed by the healthy MR variety of HG563 i.e. $21.55 \mathrm{mg} / \mathrm{g}$ and $20.8 \mathrm{mg} / \mathrm{g}$ in diseased samples. The lowest amount of protein $(20.15 \mathrm{mg} / \mathrm{g})$ was analysed in the healthy MR variety GAUG 1304 which reduced in the diseased leaf samples upto $19.4 \mathrm{mg} / \mathrm{g}$ of Cluster bean.

The healthy susceptible genotypes also had comparatively more protein content than the diseased leaf samples in the same varieties. Maximum protein content $(19.05 \mathrm{mg} / \mathrm{g})$ was found in the healthy MS genotype of RGr-17-4 which decreased upto $17.4 \mathrm{mg} / \mathrm{g}$ in leaf samples whereas minimum amount $(18.6 \mathrm{mg} / \mathrm{g})$ was analysed in the healthy MS genotypes of M-83 which also reduced to $17.45 \mathrm{mg} / \mathrm{g}$ after infection of $A$. $c$. var. cyamopsidis.

\section{Phenol}

The levels of total phenols were analysed at 50 DAS in both healthy and diseased leaves of resistant and susceptible cultivars of Cluster bean. The data showed that initially healthy leaves of resistant variety GAUG1304 had maximum phenol content $7.5 \mathrm{mg} / \mathrm{g}$ and it was increased to $8.7 \mathrm{mg} / \mathrm{g}$ in diseased leaf of the same variety and it was followed by the other healthy MR variety of HG563 $(6.75 \mathrm{mg} / \mathrm{g})$ which increased to $7.85 \mathrm{mg} / \mathrm{g}$ in diseased leaf sample. The lowest phenol content was observed in the healthy MR variety RGC1033 $(6.6 \mathrm{mg} / \mathrm{g})$ which increased to $7.25 \mathrm{mg} / \mathrm{g}$ after infection of $A$. c. var. cyamopsidis in the diseased leaf sample. The healthy moderately susceptible variety $\mathrm{RGr}-17-4$ revealed the highest phenol $5.45 \mathrm{mg} / \mathrm{g}$ which increased to $6.1 \mathrm{mg} / \mathrm{g}$ in diseased leaf sample whereas healthy MS M-83 variety showed the lowest amount of phenol content $4.95 \mathrm{mg} / \mathrm{g}$ and increased upto $5.4 \mathrm{mg} / \mathrm{g}$ in diseased leaf sample.

\section{Ortho Dihydroxy Phenol}

The level of ortho-dihydroxy phenol content was also analysed in healthy and diseased leaf samples of different varieties. The healthy moderate resistant genotypes showed lower OD phenol content as compared to diseased leaves samples of these varieties. Among the different healthy MS 
variety, GAUG-1502 had maximum OD phenol content 1.35 $\mathrm{mg} / \mathrm{g}$ which increased in diseased sample $1.95 \mathrm{mg} / \mathrm{g}$ while the lowest content $(1.25 \mathrm{mg} / \mathrm{g})$ was found in healthy MS variety RGr-17-4 which also increased after infection of pathogen upto $1.55 \mathrm{mg} / \mathrm{g}$.

The diseased susceptible genotypes had higher OD phenol content in the diseased leaf samples as compared to healthy susceptible genotypes. The data of the biochemical analysis of the different varieties revealed that highest OD phenol content $(1.35 \mathrm{mg} / \mathrm{g})$ was found in healthy MS variety of GAUG 1502 which increased upto $1.95 \mathrm{mg} / \mathrm{g}$ in the diseased samples. The lowest OD phenol $(1.25 \mathrm{mg} / \mathrm{g})$ was found in healthy MS variety of RGr 17-4 which showed higher OD phenol content $(1.55 \mathrm{mg} / \mathrm{g})$ in diseased leaf sample.

\section{Total soluble sugar}

Total soluble sugars were significantly higher in resistant genotypes as compared to susceptible genotypes. Moderately resistant (MR) genotypes exhibited significantly higher levels of total soluble sugars in both healthy and diseased leaves samples. The genotypes RGC 1033 had highest total soluble sugar content $10.8 \mathrm{mg} / \mathrm{g}$ which was reduced in diseased sample $6.2 \mathrm{mg} / \mathrm{g}$. The lowest level of total soluble sugar $(8.8$ $\mathrm{mg} / \mathrm{g}$ ) was found in the healthy MR variety of HG563 which also got down after infection upto $6.15 \mathrm{mg} / \mathrm{g}$.

The healthy moderately susceptible varieties showed the higher total sugar content than the diseased one of the same varieties in which maximum content $(7.4 \mathrm{mg} / \mathrm{g}$ ) was showed by the healthy MS variety GAUG 1502 and $5.4 \mathrm{mg} / \mathrm{g}$ in diseased sample while the lowest content $(6.3 \mathrm{mg} / \mathrm{g})$ was found in healthy MS variety of M-83 which also reduced in diseased sample $4.2 \mathrm{mg} / \mathrm{g}$.

\section{Reducing sugar}

The results indicated that the reducing sugar content was higher in healthy leaves of resistant varieties than the susceptible genotypes. In healthy moderately resistant genotypes RGC 1033 had maximum reducing sugar content $(8.15 \mathrm{mg} / \mathrm{g})$ which decreased in diseased sample to $4.3 \mathrm{mg} / \mathrm{g}$. The lowest reducing sugar content $(6.2 \mathrm{mg} / \mathrm{g})$ was found in healthy MR variety which decreased upto $4.35 \mathrm{mg} / \mathrm{g}$ after infection of A.c. var. cyamopsidis in Cluster bean.

The healthy moderately susceptible variety also showed highest reducing sugar content than the diseased leaf samples. The healthy MS variety RGr-17-4 had highest reducing sugar content $5.25 \mathrm{mg} / \mathrm{g}$ which decreased in the diseased sample. The healthy MS variety M-83 had lowest reducing sugar 4.7 $\mathrm{mg} / \mathrm{g}$ which reduced in the diseased samples.

\section{Chlorophyll}

Healthy leaf of resistant cultivar has got more amount of total chlorophyll than the diseased leaf of the same varieties and other susceptible varieties. The highest chlorophyll content $(2.3 \mathrm{mg} / \mathrm{g})$ was found in the healthy moderately resistant (MR) variety of RGC1033 and diseased leaf $(0.9 \mathrm{mg} / \mathrm{g})$ which was followed by the other MR variety i.e. HG563 $(1.85 \mathrm{mg} / \mathrm{g})$ and diseased leaf $(0.75 \mathrm{mg} / \mathrm{g})$, GAUG1304 $(1.75 \mathrm{mg} / \mathrm{g})$ and diseased leaf $(0.65 \mathrm{mg} / \mathrm{g})$.

The data showed that there was drastically reduced content of chlorophyll was observed in all the susceptible varieties. The maximum chlorophyll content was found in healthy moderately susceptible (MS) variety of GAUG-1502 (1.75 $\mathrm{mg} / \mathrm{g})$ and diseased leaf $(0.5 \mathrm{mg} / \mathrm{g})$ which was followed by the other MS variety RGr-17-4 (1.25 mg/g) and diseased leaf $(0.45 \mathrm{mg} / \mathrm{g})$. The lowest chlorophyll content was found in healthy MS variety of M-83 $(1.05 \mathrm{mg} / \mathrm{g})$ and diseased leaf $(0.4 \mathrm{mg} / \mathrm{g})$.

Table 1: Biochemical changes in Cluster bean leaves due to Alternaria blight leaf infection

\begin{tabular}{|c|c|c|c|c|c|c|c|c|c|c|c|c|c|}
\hline \multicolumn{2}{|c|}{ Variety } & \multirow{2}{*}{\begin{tabular}{|c|}
$\begin{array}{c}\text { Protein } \\
(\mathbf{m g} / \mathbf{g})\end{array}$ \\
23.35 \\
\end{tabular}} & \multirow{2}{*}{\begin{tabular}{|c|}
$\begin{array}{c}\text { Decreased } \\
\text { over } \\
\text { Healthy } \\
(\%)\end{array}$ \\
3.85 \\
\end{tabular}} & \multirow{2}{*}{\begin{tabular}{|c|}
$\begin{array}{l}\text { Phenol } \\
(\mathbf{m g} / \mathbf{g})\end{array}$ \\
6.60 \\
\end{tabular}} & \multirow{2}{*}{\begin{tabular}{|c|c|}
$\begin{array}{c}\text { Increased } \\
\text { over } \\
\text { healthy } \\
(\%)\end{array}$ \\
9.84 \\
\end{tabular}} & \multirow{2}{*}{\begin{tabular}{|c|}
$\begin{array}{c}\text { O D } \\
\text { Phenol } \\
(\mathbf{m g} / \mathbf{g})\end{array}$ \\
1.50 \\
\end{tabular}} & \multirow{2}{*}{\begin{tabular}{|c|c|}
$\begin{array}{c}\text { Increased } \\
\text { over } \\
\text { healthy } \\
(\%)\end{array}$ \\
33.33 \\
\end{tabular}} & \multirow{2}{*}{\begin{tabular}{|c|}
$\begin{array}{c}\text { Total } \\
\text { soluble } \\
\text { sugar } \\
(\mathbf{m g} / \mathbf{g})\end{array}$ \\
10.80 \\
\end{tabular}} & \multirow{2}{*}{\begin{tabular}{|c|c|}
$\begin{array}{c}\text { Decreased } \\
\text { over } \\
\text { healthy } \\
(\%)\end{array}$ \\
42.59 \\
\end{tabular}} & \multirow{2}{*}{\begin{tabular}{|c|}
$\begin{array}{c}\text { Reducing } \\
\text { sugar } \\
(\mathbf{m g} / \mathbf{g})\end{array}$ \\
8.15 \\
\end{tabular}} & \multirow{2}{*}{ 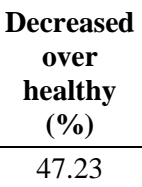 } & \multirow{2}{*}{\begin{tabular}{|c|}
$\begin{array}{c}\text { Chlorophyll } \\
(\mathbf{m g} / \mathbf{g})\end{array}$ \\
2.30 \\
\end{tabular}} & \multirow{2}{*}{\begin{tabular}{|c}
$\begin{array}{c}\text { Decreased } \\
\text { over } \\
\text { healthy } \\
(\%)\end{array}$ \\
60.86 \\
\end{tabular}} \\
\hline RGC1033 & Healthy & & & & & & & & & & & & \\
\hline (MR) & Diseased & 22.45 & & 7.25 & & 2.00 & & 6.20 & & 4.30 & & 0.90 & \\
\hline RGr-17-4 & Healthy & 19.05 & 8.66 & 5.45 & 11.92 & 1.25 & 24.00 & 7.10 & 38.73 & 5.25 & 49.52 & 1.25 & 64.00 \\
\hline (MS) & Diseased & 17.40 & & 6.10 & & 1.55 & & 4.35 & & 2.65 & & 0.45 & \\
\hline HG563 & Healthy & 21.55 & 3.48 & 6.75 & 16.29 & 1.50 & 60.00 & 8.80 & 30.11 & 6.20 & 29.83 & 1.85 & 64.86 \\
\hline (MR) & Diseased & 20.80 & & 7.85 & & 2.40 & & 6.15 & & 4.35 & & 0.75 & \\
\hline M-83 & Healthy & 18.60 & 6.18 & 4.95 & 9.09 & 1.30 & 50.00 & 6.30 & 33.33 & 4.70 & 23.40 & 1.05 & 61.90 \\
\hline (MS) & Diseased & 17.45 & & 5.40 & & 1.95 & & 4.20 & & 3.60 & & 0.40 & \\
\hline GAUG-1502 & Healthy & 18.90 & 3.17 & 5.15 & 11.65 & 1.35 & 44.44 & 7.40 & 27.03 & 5.15 & 29.12 & 1.50 & 66.66 \\
\hline (MS) & Diseased & 18.30 & & 5.75 & & 1.95 & & 5.40 & & 3.65 & & 0.50 & \\
\hline GAUG1304 & Healthy & 20.15 & 3.72 & 7.50 & 16.00 & 1.75 & 54.28 & 9.45 & 33.33 & 6.75 & 31.11 & 1.75 & 57.14 \\
\hline (MR) & Diseased & 19.40 & & 8.70 & & 2.70 & & 6.30 & & 4.65 & & 0.65 & \\
\hline \multicolumn{2}{|c|}{$\mathrm{SE} \pm(\mathrm{m})$} & 0.60 & & 0.54 & & 0.32 & & 0.51 & & 0.35 & & 0.15 & \\
\hline \multicolumn{2}{|c|}{$\mathrm{CD}$} & 0.19 & & 0.17 & & 0.10 & & 0.16 & & 0.11 & & 0.05 & \\
\hline
\end{tabular}



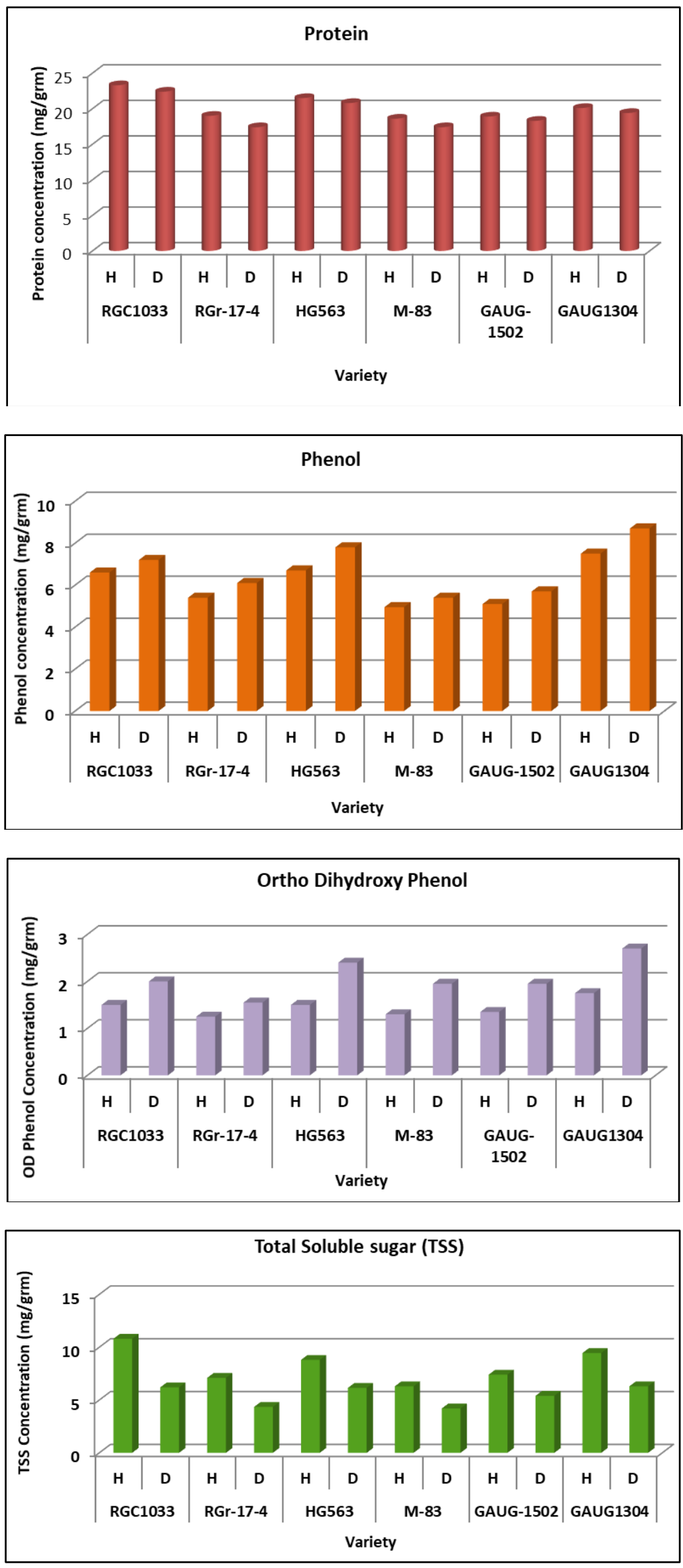

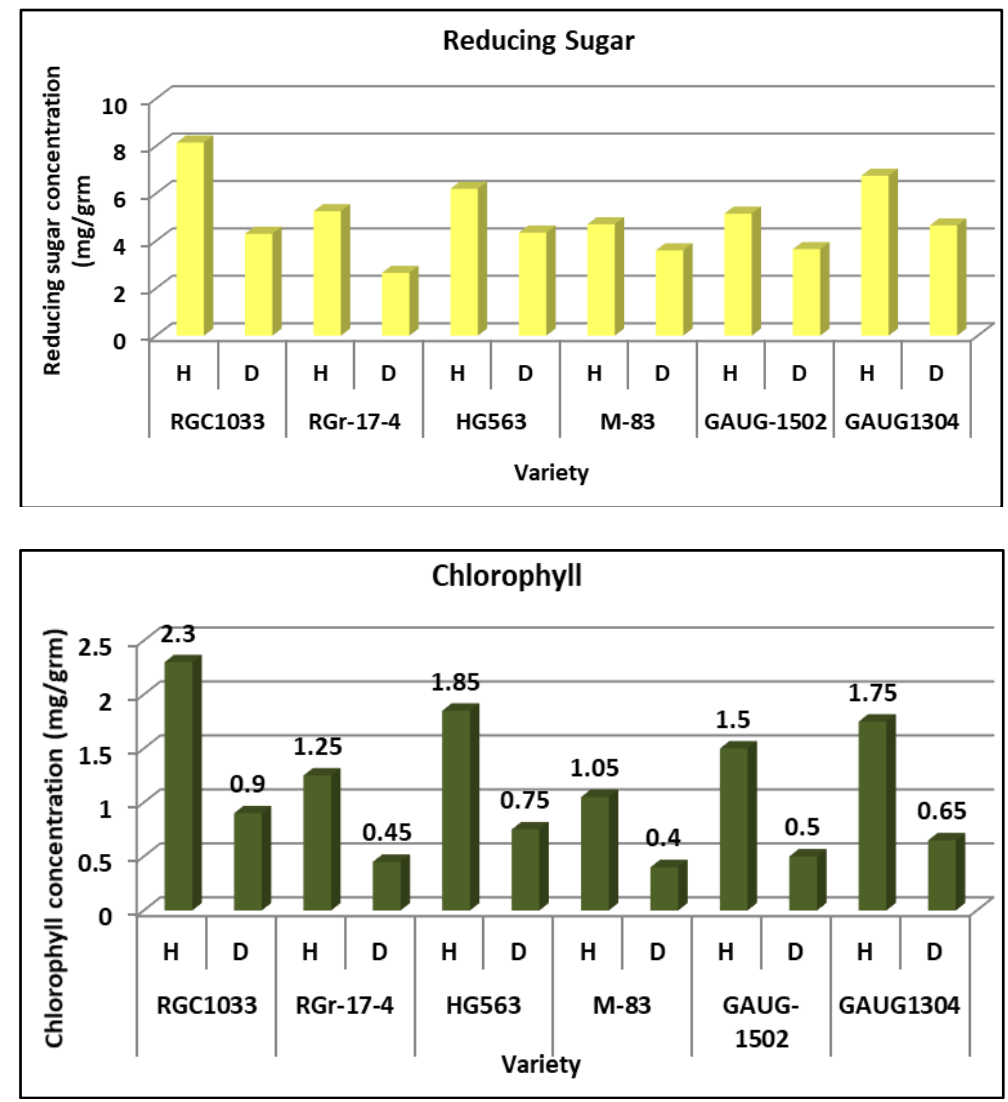

Fig 1: Biochemical changes in C. tetragonoloba leaves due to Alternaria blight leaf infection

The data indicate that moderately resistant genotypes had higher total chlorophyll, carotenoid, total soluble sugars, total proteins, total phenols and OD phenol content than the susceptible genotypes and the decrease in various biochemical factors following the infection was at lower rates in moderately resistant genotypes.

The moderately resistant genotypes had higher chlorophyll content than the susceptible genotypes. There was a significant difference in the chlorophyll levels of healthy and diseased leaves of the genotype. After pathogenesis, the susceptible genotype recorded maximum reduction and moderately resistant genotype recorded minimum reduction per cent. Higher chlorophyll content might be associated with host's resistant to black spot disease of rapeseed mustard caused by Alternaria brassicae (Kolte and Awasthi 1987) ${ }^{[17]}$. The reduction in chlorophyll may be attributed to toxic metabolites produced by pathogen which may destroy the chloroplast (Senthil et al., 2010) ${ }^{\text {[31] }}$ or to the inhibition of synthesis of chlorophyll rather than the degradation of preexisting pigments (Ammajamma and Patil, 2008) ${ }^{[1]}$.

The findings revealed that total sugar and reducing sugar contents were higher in healthy leaves of resistant genotypes as compared to susceptible ones. Total soluble sugars were significantly higher in moderately resistant genotype. Moderately resistant genotypes exhibited significantly higher levels of total soluble sugars in both healthy and diseased leaves. A significant reduction in the total soluble sugar levels was observed in the genotype after infection, but the per cent depletion was at higher rates in susceptible genotype compared to moderately resistant genotype. Sunkad and Kulkarni (2006) [38] reported higher levels of sugars in resistant and moderately resistant groundnut genotypes than susceptible genotypes in response to Puccinia arachidis infection. The changes in carbohydrate content in response to infection can be attributed to direct parasite utilization and indirectly to the altered host metabolism. The depletion may be attributed to the secretion of certain metabolites to degrade the carbohydrates and used by the respective pathogen for its growth (Ponmurugan and Baby, 2007) ${ }^{[25]}$.

In diseased leaves, the amount of reducing sugar was decreased in both resistant and susceptible genotype. But, this decrease in sugar content was at higher rates in susceptible varieties compared to moderately resistant variety. It may be due to some aspects of biochemical defence mechanisms, operating in the resistant host. It may be the cause of biochemical chemical change occurred due to infection by pathogen. So, the study clears that the low amount of carbohydrates in resistant genotypes may be responsible for resistant of genotypes. These results concerned with higher amount of sugars (total soluble sugar and reducing) are in agreement with the earlier findings of many workers. Sindhan and Jaglan (1987) ${ }^{[33,34]}$ and Sindhan et al. (1987) ${ }^{[33,34]}$ reported lower amounts of sugars (reducing and total) in Cercospora resistant groundnut cultivars as compared to the susceptible one. Suryawanshi et al., (1993) ${ }^{[39]}$ also reported higher amounts of sugars (reducing and total) in $P$. personata susceptible groundnut Cv. JL-24. Similarly, Waghmare, et al., (2012) ${ }^{[41]}$ reported that the plant infected with leaf spot of rose caused by Alternaria alternata showed a decrease in the quantity of total sugar and reducing sugar compared to the healthy plant. So, present study revealed that the low amount of carbohydrates in resistant genotypes imparts resistant against $C$. truncatum.

Moderately resistant genotype showed maximum and significantly higher protein content in comparison to susceptible genotypes. Post pathogenesis, showed reduced levels of total proteins in the genotype. The decline in proteins was more pronounced in susceptible genotype. Ponmurugan and Baby (2007) ${ }^{[25]}$ reported higher protein content in tolerant tea cultivars than the susceptible to 
Phomopsis theae infection. Although higher protein in resistant genotypes may serve as index of resistant, its role remains yet to be elucidated (Dhingra et al., 2003) ${ }^{[9,10]}$. Changes in protein occur when the pathogen penetrates the host cells resulting in disturbances in protein and related metabolisms (Khan et al., 2001) ${ }^{[16]}$. The reduction in the protein content might be due to blockage of protein synthesis or degradation of proteins in the host plants (Sunkad and Kulkarni 2006) ${ }^{[38]}$.

Maximum and significantly higher levels of total phenols and OD phenol were observed in moderately resistant genotype whereas the susceptible genotype recorded lower levels of total phenols than moderately resistant genotype. Post pathogenesis, the healthy leaves of moderately resistant genotypes contained higher total phenol and OD phenol contents than the moderately susceptible genotype. In the diseased leaves, the total phenols increased after infection. These findings are in conformity with those reported earlier by many workers. Waghmare et al., (2012) ${ }^{[41]}$ reported that the rose plants infected with leaf spot of rose showed significant increase in phenol content as compared to the healthy plant. Similarly, higher amounts of phenols were recorded for leaf spot resistant in groundnut cultivars by Gupta et al., (1985) ${ }^{[11]}$, Sindhan and Jaglan (1987) ${ }^{[33,34]}$ and Sindhan et al., (1987) ${ }^{[33,34]}$; in cotton cv. Akala for Alternaria resistant by Bashan (1986) ${ }^{[3]}$; in mustard cultivars for Alternaria blight tolerance by Gupta et al., (1990) ${ }^{[12]}$, Singh et al., (1999) ${ }^{[35]}$, Saxena and Prasad (2003) ${ }^{[29]}$ and Atwal et al., (2004) [2]; for rust resistant in groundnut cultivars by Sunkad and Kulkarni, (2006) ${ }^{[38]}$, for A. solani resistant in tomato cultivars by Mate et al., (2007) ${ }^{[22]}$ and for anthracnose resistant in French bean cultivars by Gupta et al., (2010) [13] were reported earlier, which supports the present findings.

But Madhavi et al., (2005) ${ }^{[20]}$ reported the contradict findings that species of wild sunflower resistant to Alternaria helianthi possessed higher levels of both constitutive phenols as compared to susceptible genotypes. The depletion of phenols after infection can be related to sugar depletion also. The unavailability of sugars as substrates for phenol synthesis can lead to the reduced phenolic levels (Ponmurugan and Baby 2007) ${ }^{[25]}$. It is possible that infected plants are unable to manufacture the phenols or might have used phenols as substrates for toxin production (Siddiqua and Kashem 1993) [32].

\section{Conclusion}

Protein, total sugar, reducing sugar and chlorophyll contents were decreased with the infection of pathogen in the diseased sample whereas the total phenol and O-dihydroxy phenol were increased with increasing the disease in the diseased leaf sample of different varieties.

\section{Acknowledgement}

The authors are grateful to Dean, College of Agriculture Gwalior, for Providing the field and lab facility for the Research work.

\section{References}

1. Ammajamma R, Patil PV. Biochemical factors imparting rust (Phakospora pachyrhizi) resistance in soybean. Karnataka J Agric. Sci. 2008; 21:65-69.

2. Atwal A, Ramandeep K, Munshi SK, Mann APS. Biochemical changes in relation to Alternaria leaf blight in Indian mustard. P1. Dis. Res. 2004; 19:57-59.
3. Bashan Y. Phenols in cotton seedlings resistant and susceptible to Alternaria macrospora. J Phytopath. 1986; 116:1-10.

4. Bibi N, Sattar A, Chaudhary MA. Variation of phenolic compounds in rapeseed varieties grown at Peshawar. Pakistan J Sci. Ind. Res. 1993; 36(5):195-198.

5. Bora M, Joshi N. A study on variation in biochemical aspects of different tree species with tolerance and performance index. The Bioscan. 2013, 2014; 9(1):59-63,

6. Bradford MM. A rapid and sensitive method for identification of microgram quantities of protein utilizing the principle of protein-dye binding. Ann. Biochem. 1976; 72:248-254.

7. Bray HG, Thorpe WV. Analysis of phenolic compounds of interest in metabolism. Methods. Biochem. Anal. 1954; 1:27-52.

8. Dhawan K, Yadav TP, Kaushik CD, Thakral SK. Changes in phenolic compounds and sugar in relation to white rust of Indian mustard. Crop Imp. 1981; 8:142-144.

9. Dhingra K, Mehta HR, Sangwan MS. Effect of culture filtrate of Alternaria brassicae on biochemical constitutents of calli of brassicas. J Mycol. Pl. Path. 2003; 33:51-55.

10. Dhingra K, Madhu J, Arora A, Neelima H, Aujla IS. Biochemical characteristic imparting resistance against Alternaria blight in cauliflower genotypes. Agric. Sci. Digest. 2003; 33(2):92-97.

11. Gupta PP, Gupta SK, Kaushik CD, Yadava TP. Biochemical changes in leaf surface washings of groundnut due to tikka disease, $C$. personata. Indian Phytopath. 1985; 38:339-340.

12. Gupta SK, Gupta PP, Yadava TP, Kaushik CD. Metabolic changes in mustard due to Alternaria leaf blight. Indian Phytopath. 1990; 43:64-69.

13. Gupta S, Mallick SA, Gupta M. Role of oxidative enzymes and biochemical constituents in imparting resistance to French bean varieties against bean anthracnose. Indian Phytopath. 2010; 63:47-50.

14. Hiscox JD, Israelstam GF. A method for the extraction of chlorophyll from leaf tissue without maceration. Canadian J. Bot. 1979; 57:1332-1334.

15. Hymowitz T. The trans-domestication concept as applied to guar. Econ. Bot. 1972; 26:49-60.

16. Khan AJ, Deadman ML, Srikandakumar A, Al-Maqbali YM, Rizvi SG, Al-Sabahi J. Biochemical changes in sorghum leaves infected with leaf spot pathogen Drechslera sorghicola. Pl. Path. J. 2001; 17:342-46.

17. Kolte SJ, Awasthi RP, Vishwanath J. Assessment of yield losses due to Alternaria blight in rapeseed and mustard. Indian Phytopath. 1987; 40(2):209-211.

18. Kumar J, Rathi AS, Panwar MS. Biochemical changes in pearl millet leaves due to rust infection. Forage Res. 2002; 28:67-69.

19. Kumar N, Verma S. Quantitative changes in sugar and phenolic contents of Brassica leaves induced by Alternaria brassicae infection. Inter. J Pl. Protect. 2010; 3(1):28-30.

20. Madhavi KJ, Sujatha M, Reddy RR, Chander RS. Biochemical characterization of resistance against Alternaria helianthi in cultivated and wild sunflowers. Helia, 2005; 28:13-24.

21. Mahadevan A, Sridhar R. In: Methods in Physiological Plant Pathology (3rd edn.) Sivakami Publications, Chennai, 1986, 183-184. 
22. Mate GD, Gupta VR, Totawar MV. Biochemical changes in tomato due to infection of Alternaria solani. J Pl. Dis. Sci. 2007; 2:241-242.

23. Mathpal P, Punetha H, Tewari AK, Agrawal S. Biochemical defense mechanism in rapeseed-mustard genotypes against Alternaria blight disease. J Oilseed Brassica, 2011; 2(2):87-94.

24. Neeraj S, Verma S. Quantitative changes in sugar and phenolic contents of Brassica leaves induced by Alternaria brassicae infection. Inter. J Pl. Protect. 2010; 3(1):28-30.

25. Ponmurugan $\mathrm{P}$, Baby UI. Morphological, physiological and biochemical changes in resistant and susceptible cultivars of tea in relation to Phomopsis disease. Plant Path. J. 2007; 6:91-94.

26. Priya P, Harika D. A review on multiple uses of Cyamopsis tetragonoloba. (Clusterbean). Indian J Avd. Tech. Eng. Sci. 2016; 4(1):55-59.

27. Pryor BM, Gilbertson RL. Relationships and taxonomic status of Alternaria radicina, A. carotiincultae, and $A$. petroselini based upon morphological, biochemical, and molecular characteristics. Mycologia. 2002; 94:49-61.

28. Sadasivam S, Manickam A. Biochemical methods for agriculture sciences, Wiley Eastern Limited, New Delhi, 1992, 11-12.

29. Saxena D, Prasad R. Biochemical changes in resistant and susceptible cultivars of mustard for disease resistance against Alternaria blight. Indian Phytopath. 2003; 56:313-314.

30. Sharma SR. Yield loss in clusterbean caused by Alternaria cyamopsidis. Veg. Sci. 1981; 8(1):58-63.

31. Senthil V, Ramasamy P, Elaiyaraja C, Ramola E. Some phytochemical properties affected by the infection of leaf spot disease of Cucumis sativus (Linnaeus) caused by Penicillium notatum. African J. Basic Appl. Sci. 2010; 2:64-70.

32. Siddiqua A, Kashem MA. Total phenol and soluble sugar in rice leaf sheath in relation to resistance to sheath blight pathogen. Indian J Agric. Res. 1993; 27:57-63.

33. Sindhan GS, Jaglan BS, Parashar RD. Changes in phenols and carbohydrates in resistant and susceptible cultivars of groundnut in relation to tikka disease. Pl. Dis. Res. 1987; 2:100-101.

34. Sindhan GS, Jaglan BS. Role of phenolic compounds and carbohydrates in resistance to tikka leaf spot. Indian $\mathrm{J}$. Mycol. Plant Path. 1987; 17:141-144.

35. Singh DN, Singh NK, Srivastav S. Biochemical and morphological characters in relation to Alternaria blight resistance in rapeseed-mustard. Ann. Agric. Res. 1999; 20:472-477.

36. Somogyi M. Notes on sugar determination. J Biol Chem. 1952; 195:19-23.

37. Sowell PG. The effect of seed treatment on seed borne pathogens of guar. Pl. Dis. Rep. 1965; 49:895-897.

38. Sunkad G, Kulkarni S. Studies on structural and biochemical mechanisms of resistance in groundnut to Puccinia arachidis. Indian Phytopath. 2006; 59:323-28.

39. Suryawanshi AP, Mayee CD, Apet KT. Biochemical changes in sugars and amino acids of groundnut leaves during Phaeoisariopsis personata pathogenesis. Proc. Indian Phytopath. Soc. (Western Zone), 1993, 51-53.

40. Vavilov NI. The origin, variation, immunity and breeding of cultivated plants. Chronica Bot. 1951; 13:2-6.

41. Waghmare MB, Waghmare RM, Kamble SS. Biochemical changes in Rosa floribunda infected with
Carbendazim resistant and sensitive isolate of Alternaria Alternata. The Bioscan. 2012; 7(1):101-102.

42. Yadav OP, Yadav TP, Kumar P, Gupta SK. Inheritance of phenol and protein in relation to white rust (Albugo candida) resistance in Indian mustard. Indian $\mathbf{J}$ Gen. 1996; 56(3):256-261. 